\title{
Thyroid hemiagenesis: a case report
}

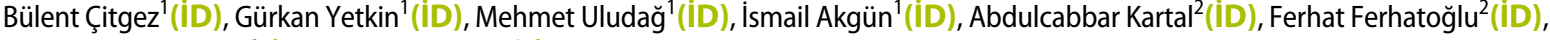 \\ Fevziye Kabukçuoğlư ${ }^{3}$ (iD), Adem Akçakaya ${ }^{1}$ (ID) \\ ${ }^{1}$ Department of General Surgery, Şişli Etfal Training and Research Hospital, İstanbul, Turkey \\ ${ }^{2}$ Department of General Surgery, Istanbul Okan University School of Medicine, İstanbul, Turkey \\ ${ }^{3}$ Department of Pathology, Şişli Etfal Training and Research Hospital, İstanbul, Turkey
}

\section{ABSTRACT}

Thyroid hemiagenesis is a rare entity in the literature. Developmental hemi-thyroid anomalies can result from either an abnormal descent or an agenesis of one lobe of the thyroid gland. This study aimed at presenting a thyroid hemiagenesis case incidentally diagnosed by neck ultrasonography (USG), who had complaints of pain and swelling in the neck. USG examination revealed lack of left thyroid lobe and multiple nodules in the right lobe. Fine Needle Aspiration Biopsy (FNAB) showed follicular neoplasia, and right subtotal thyroidectomy was performed. We report the rarity of the condition and emphasize the role of imaging techniques in preoperative diagnosis and subsequent management.

Keywords: Thyroid, hemiagenesis, surgery

Cite this article as: Çitgez $B$, Yetkin $G$, Uludağ M, Akgün I, Kartal A, Ferhatoğlu F, Kabukçuoğlu F, Akçakaya A. Thyroid hemiagenesis: a case report. Turk J Surg 2019; 35 (4): 329331.

\section{Corresponding Author}

Bülent Çitgez

E-mail: bcitgez@yahoo.com

Received: 05.06.2015

Accepted: 13.07.2015

Available Online Date: 16.12 .2019

O Copyright 2019 by Turkish Surgical Society Available online at www.turkjsurg.com

DOI: $10.5578 /$ turkjsurg. 3228

\section{INTRODUCTION}

Thyroid hemiagenesis is a rare thyroid pathology characterized by the deficient development of a single thyroid lobe or both a thyroid lobe and the isthmus (1), which was first reported by Handfield-Jones in 1866 (2). Thyroid hemiagenesis is usually identified incidentally with imaging techniques for the investigation of thyroid hormone disorders or evaluation of other complaints. A prevalence study with USG has indicated an incidence of $0.05 \%$ (3). We aimed to present a thyroid hemiagenesis case incidentally diagnosed by neck ultrasonography, who presented with complaints of pain and swelling in the neck.

\section{CASE REPORT}

The patient was a 32-year-old female, under follow-up for type-Il diabetes mellitus (DM) for 7 years, who was presented with chief complaint of neck pain and swelling and underwent neck ultrasonography. Ultrasonography examination revealed lack of left thyroid lobe and multiple nodules in the right lobe, the largest measuring 12.8 x $7.1 \mathrm{~mm}$. Laboratory values were as follows; FT3: $2.84 \mathrm{pg} / \mathrm{mL}$, FT4: $1.15 \mathrm{ng} / \mathrm{dL}, \mathrm{TSH}$ : $2.8 \mathrm{uU} / \mathrm{mL}$ (euthyroidism). Fine Needle Aspiration Biopsy showed follicular neoplasia, and she was referred to our out-patient clinic. Neck examination was within normal limits. Scintigraphy examination revealed lack of left thyroid lobe and hypoactive nodules in right lobe (Figure 1). Surgery was planned. Patient underwent right lobectomy. Left thyroid region was empty and a parathyroid-like yellow tissue was present in that region (Figure 2). Post-operative period was uneventful and the patient was discharged on the second post-operative day. Informed consent was obtained from the patient for both operation and presentation.

\section{DISCUSSION}

According to the literature, thyroid hemiagenesis is associated with a female predominance of 3:1, and it more often affects the left lobe, at a ratio of $4: 1$, as in our patient $(3,4)$. The etiology of thyroid hemiagenesis is not clearly known. Aberrant thyroid migration and genetic component involving mutations in one or several genes that are known to control thyroid morphogenesis/migration have been suggested (5). The isthmus was present in about half of the reported cases although it was absent in our patient $(6,7)$. These patients may have follicular and papillary neoplasms, Graves' disease with thyrotoxicosis, hypothyroidism or hyperthyroidism and as in our case, surgery may be indicated (6-8). 

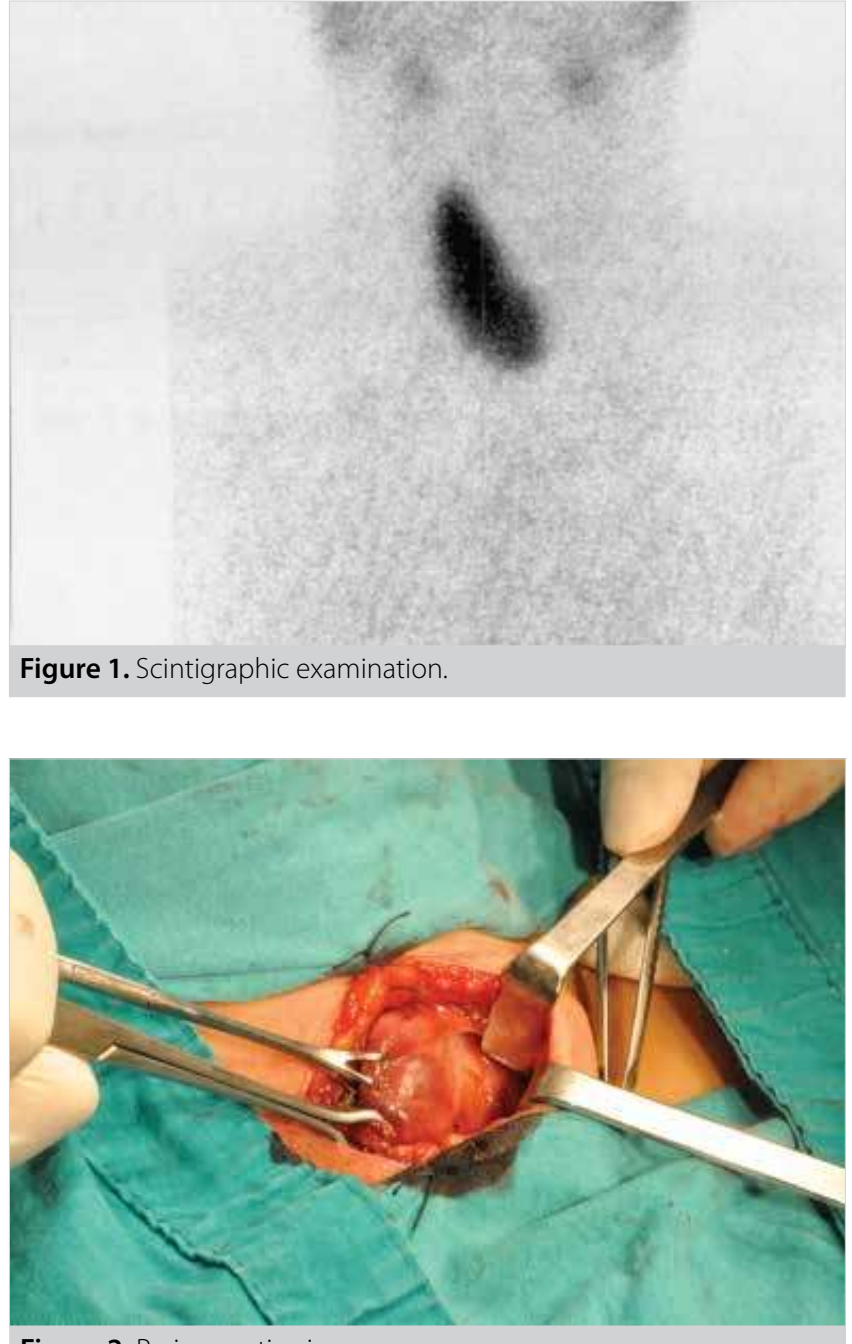

Figure 2. Peri-operative image.

The incidence of thyroid hemiagenesis is uncertain since patients are usually in euthyroid state without any abnormalities. There could be many cases of undiagnosed thyroid hemiagenesis, or as in our case, diagnosed incidentally by an imaging technique (8).

Many studies indicate that USG has the key role in diagnosing thyroid hemiagenesis, and thyroid scintigraphy, laboratory tests and FNAB aid in the detection of accompanying thyroid gland pathologies and imaging ectopic thyroid tissue (3-7). USG is not only useful in lack of a single lobe or single lobe with the isthmus, but also detects hyperplasia in the lobe, or as in our case, additional pathologies such as nodules (8). Scintigraphy shows substance uptake of the remaining thyroid tissue and may detect ectopic thyroid tissues such as a sublingual thyroid, not revealed by ultrasound, which strays the diagnosis from hemiagenesis. Ectopic thyroid tissue was absent in the scintigraphic image of our patient, whereby the diagnosis of thyroid hemiagenesis was confirmed pre-operatively $(8,9)$. The pathologic study of the FNAB sample from the nodule, identified in USG, revealed follic- ular neoplasia and surgery was indicated; scintigraphy was performed for investigation of ectopic focus.

Thyroid hemiagenesis is usually diagnosed incidentally; pre-operative thyroid gland imaging is useful for diagnosis of the anomaly even if laboratory data are within normal limits. We assume that pre-operative diagnosis of the anomaly prevents unnecessary surgical interventions and decreases possible secondary morbidity.

\section{CONCLUSION}

Thyroid hemiagenesis is a rare developmental anomaly of unknown etiology, usually identified incidentally with imaging techniques. Pre-operative diagnosis of thyroid hemiagenesis prevents unnecessary surgical interventions.

Informed Consent: Written informed consent was obtained from all the patients who participated in this study.

Peer-review: Externally peer-reviewed.

Author Contributions: Concept - B.Ç., A.K.; Design - M.U.; Supervision - B.Ç., G.Y.; Resource - I.A., F.F.; Materials - F.K.; Data Collection and/or Processing - B.Ç., M.U.; Analysis and/or Interpretation - A.A.; Literature Search - B.Ç.; Writing Manuscript - B.Ç.; Critical Reviews - M.U., A.K.

Conflict of Interest: The authors have no conflicts of interest to declare.

Financial Disclosure: The authors declared that this study has received no financial support.

\section{REFERENCES}

1. Aslaner A, Aydin M, Ozdere A. Multinodular goitre with thyroid hemiagenesis: a case report and review of the literature. Acta Chir Belg 2005;105(5):528-30.[CrossRef]

2. Jones H. Handbuch der Systematischen Anatomie des Menschen. In: Henle J (ed). Sohn: Freidrich Vleiwig und Braunschweig, 1866:538.

3. Mikosch P, Gallowitsch HJ, Kresnik E, Molnar M, Gomez I, Lind P. Thyroid hemiagenesis in an endemic goiter area diagnosed by ultrasonography: report of sixteen patients. Thyroid 1999;9(11):1075-84.[CrossRef]

4. Bhartiya S, Verma A, Basu S, Shukla V. Congenital thyroid hemiagenesis with multinodular goiter. Acta Radiol Short Rep 2014;3(9):1-4. [CrossRef]

5. Melnick JC, Stemkoowski PE. Thyroid hemiagenesis (hockey stick sign): a review of the world literature and repert of four cases. J Clin Endocrinol Metab 1981;52:247-51.[CrossRef]

6. McLean R, Howard N, Murray IPThyroid dysgenesis in monozygotic twins: variants identified by scintigraphy. Eur J Nucl Med 1985;10:3468. [CrossRef]

7. Chen LM, Sherman AH. MR imaging of thyroid hemiagenesis. Am J Roentgenol 1997;169:1200-1.[CrossRef]

8. Bergami G, Barbuti D, Di Mario M. Echographic diagnosis of thyroid hemiagenesis. Minerva Endocrinol 1995;20:195-8.

9. Kocakusak A, Akinci M, Arikan S, Sunar H, Yucel AF, Senturk O. Left thyroid lobe hemiagenesis with hyperthyroidism: report of a case. Surg Today 2004;34(5):437-9. [CrossRef]

10. Karabay N, Comlekci A, Canda MS, Bayraktar F, Degirmenci B. Thyroid hemiagenesis with multinodular goiter: a case report and review of the literature. Endocr J 2003;50(4):409-13. [CrossRef] 


\section{OLGU SUNUMU-ÖZET}

Turk J Surg 2019; 35 (4): 329-331

\section{Tiroid hemiagenezisi: Bir olgu sunumu}

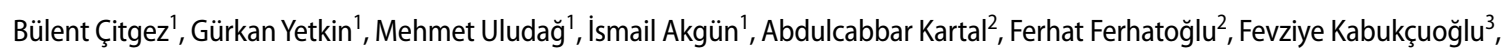
Adem Akçakaya'

${ }^{1}$ Şişli Etfal Eğitim ve Araştırma Hastanesi, Genel Cerrahi Kliniği, İstanbul, Türkiye

${ }^{2}$ Okan Üniversitesi Tıp Fakültesi, Genel Cerrahi Anabilim Dalı, İstanbul, Türkiye

${ }^{3}$ Şişli Etfal Eğitim ve Araştırma Hastanesi, Patoloji Kliniği, İstanbul, Türkiye

\section{ÖZET}

Tiroid hemiagenezisi literatürde çok seyrek görülür. Hemitiroid anomalilerinin oluşumu, bir tiroid lobunun anormal inişine ya da tamamen yokluğuna bağlı olarak oluşabilir. Bir tiroid hemiagenezi olgusu, boyunda şişlik ve ağrı şikayetleri nedeniyle çekilen ultrasonografi (USG) ile insidental olarak saptanıp polikliniğimize başvurdu. USG'de sol tiroid lobunun olmadığı ve sağ tiroid lobunda multipl nodüllerin olduğu görüldü. İnce iğne aspirasyon biyopsisinde folliküler neoplazi tespit edilmesi üzerine sağ total tiroidektomi uygulandı. Biz seyrek olarak görülen bu hastalığı ve görüntüleme tekniklerinin preoperatif tanı ve tedavideki rolünü vurgulamak istedik.

Anahtar Kelimeler: Tiroid, hemiagenezi, cerrahi

DOi: $10.5578 /$ turkjsurg. 3228 